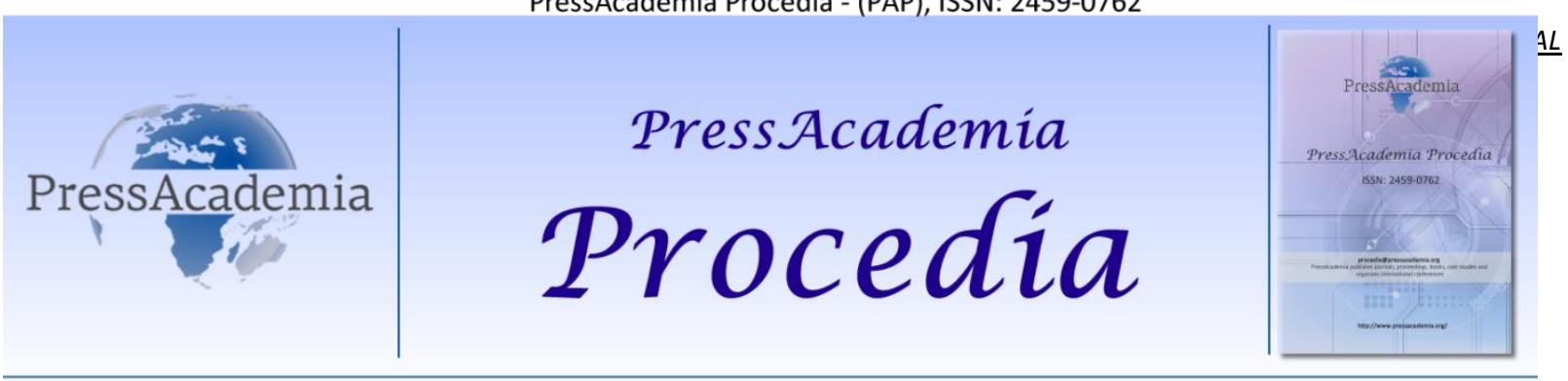

2nd World Conference on Technology, Innovation and Entrepreneurship

May 12-14, 2017, Istanbul, Turkey. Edited by Sefer Şener

\title{
INVESTIGATION OF THE RELATIONSHIP BETWEEN CYBER BULLYING BEHAVIOURS AND INTERNET ADDICTION IN ADOLESCENTS
}

\author{
DOI: 10.17261/Pressacademia.2017.526 \\ PAP-WCTIE-V.4-2017(18)-p.123-128
}

Gozde Cinar ${ }^{1}$, Utku Beyazit ${ }^{2}$, Yesim Yurdakul ${ }^{3}$, Aynur Butun Ayhan ${ }^{4}$

${ }^{1}$ Ministry of National Education,Milli Saraylar Kindergarten, İstanbul,Turkey, gozdebaydemircinar@gmail.com

${ }^{2}$ Near East University,Psychology Department,Nicosia, Cyprus. proz2proz@yahoo.com

${ }^{3}$ Ministry of National Education, Ismail Iltemir Primary School, Antalya,Turkey. yesim.yurdakul.yy@gmail.com

${ }^{4}$ Ankara University, Faculty of Health, Ankara,Turkey. a_butun@yahoo.com

\begin{abstract}
Developments in technology and widespread use of technology by young people have enabled the use of technology to enforce bullying behaviors that students have shown in schools. The malicious use of information and communication technologies has led to the observation of a tyranny called "cyber bullying" among bullying types among students in schools. This study examines the relationship between internet addiction and cyber bullying behaviors in adolescents. The sample group of the study was comprised of 239 adolescents attending to different high schools in İstanbul.In the study, "Individual Information Form", developed by the authors, was used for the collection of information data about participants, "Internet Addiction Scale" was used to assess internet addiction in adolescents and "Cyber bullying Scale" was used to assess the cyber bullying behaviours. As a result of the research between the scores of Cyberbullying Scale and the Internet addiction Scale, reveals that there is a significant positive correlation between cyberbullying and Internet addiction $(r=, 374, p<0,01)$.
\end{abstract}

Keywords: Internet, internet addıctıon, cyber bullying, addiction, adolescent JEL Codes: M30

\section{INTRODUCTION}

Interactions in the changing and modern world are causing people more stimuli to be exposed. Together with this modernization process, technological developments that bring new and different perspectives are added to human life every day. While these developments support development and change in terms of an individual point of view, they have begun to become an integral part of human life at the same time. It can be said that one of mentioned developments is internet. Internet is a widely used, permanently evolving communication network and connected with computer systems (Özen, Gülaçtı and Çıkılı, 2004). The benefits that Internet provides in many areas, being in the first place in education and training, are indisputable. However, problems appear to be caused by abuse of technology as well as the benefits that seem to be in each technological development. One of them is also internet usage and addiction. The term "Internet addiction" was first proposed by Goldberg in 1996 (Üneri and Tanıdır, 2011). Young (1996) defined the internet use as psychiatric disorder. According to Arıcak (2011), Forrester Resarch survey results show that $75 \%$ of young aged 12-15 in Europe have at least one mobile phone and age of mobile phone usage is decreasing more and more. According to Sabah-TNS Piar's research, 93\% of young 15-22 aged in Turkey are using mobile phones. Internet usage in our country has become widespread in recent years. According to results of Household Information Technologies Research conducted by the Turkish Statistical Institute (TUIK) in April (2012), results obtained of research support this information. According to Turkish Statistics Institute (TUIK) data, rates of internet and computer usage in the 16-74 age group are respectively $49,9 \%$ and $48,9 \%$. These rates in 2012 were respectively $48,7 \%$ and $47,4 \%$. While rates of computer and internet usage are $60,2 \%$ and $59,3 \%$ for males aged $16-74$, these rates are $39,8 \%$ and $38,7 \%$ for females. Computer and internet usage $59 \%$ and $58 \%$ in urban areas and $29,5 \%$ and $28,6 \%$ in rural areas. In the first three months of 2013 (January-March 2013), it was determined that $39,5 \%$ of all individuals in the 16-74 age group use the internet regularly. These results are a finding that shows widespread usage of mobile phones and internet in also Turkey as much as in technologically developed countries. 
Internet addiction becoming a problem in the worlwide can be generally defined as non preventing internet excessive usage, more needed internet time gradually, losing time importance of time without internet, behaviours arising such as extreme nervousness, tension and deterioration of individual's work, social and family life in the lack of internet. Internet addiction was defined by Cengizhan (2005) as follows; It is an addiction that is generally observed in school-age children, affecting psychological and bodily development of young and social relations negatively; in parallel with this, and this addiction is seen as use of more internet-computer usage reducing academical performance. In other words, "internet addiction is a term that describes out-control and harmful use of internet." (Öztürk, Odabaşıŏlu, Eraslan, Genç, Kalyoncu, 2007). When the reasons of internet addiction are examined, the need for socialization is seen as an important factor according to researches. Showing individuals themselves in a more exaggrated way as hiding their true identities, sharing their opinions with ease because of not to be recognized, finding internet communication easier than face-to-face communicates can be related to socialization. Besides, ease access to internet can be also considered as one of reasons of internet addiction (Cengizhan, 2005). Adolescents are one of the most susceptible groups to become addicted to the internet. According to literature, 12-18 age period is a very critical in internet addiction (Tsai and Lin, 2003; Şendağ and Odabaşı 2007).

Developments in technology and widespread use of technology by young people have enabled to students show bullying behaviours in schools by use of technology. Bullying is one of most important areas of study that has been encountered in schools today and investigated in recent years. Abuse of information communication technologies has led to the birth of a bullying type among bullying types called "cyberbullying" among schools between students. Cyberbullying is all of deliberative and repetitive, technical or relational damaging behaviours against an individual or group through computer, mobile phone and other communication technologies. Compared to traditional bullying and virtual bullying, it is understood that there are some differences between them. Firstly, it is often to determine the identity of virtual bullies because it is easy to hide the identity in the internet. Besides, the number of witnesses to virtual bullying is higher because information can be spread rapidly in the virtual environment. Finally, virtual bullying can happen all the time and even if virtual victims moves, they can't get rid of virtual bullying. Studies have shown that the most exposed people to virtual cyberbullying are young people of society revealed that adolescents using technologies tools affect on their peers' lives through their increasing threats day by day. From this information and researches, relationship between internet addiction and cyberbullying behaviours was examined in this study.

\section{DATA AND METHODOLOGY}

\subsection{Working Group}

The participants of this study were comprised of 239 adolescents attending to three different high schools in istanbul. In regards with the age groups of the participants, $66,0 \%(n=136)$ of them were between $14-16$ years old, $33,0 \%(n=68)$ of them were between $17-18$ years old and $1,0 \%(n=2)$ of them were 19 years old and older. $36,4 \%(n=75)$ of them were ninth grade student, $30,6 \%(n=63)$ of them were tenth grade student, $25,7 \%(n=53)$ of them were eleventh grade student and $7,3 \%(n=15)$ of them were twelfth grade student.

\subsection{Instruments}

In this study, "Individual Information Form", was used to in order to collect socio-demographic information about the adolescents, Cyber Bullying Scale was used to assess the cyber bullying behaviors of the adolescents participated in the study and Internet Addiction Scale was used to assess internet addiction in adolescents.

\subsubsection{Individual Information Form}

An Individual Information Form was developed by the authors in order to gather socio-demographic information about sex, age and the grades of the adolescents.

\subsubsection{Cyber Bullying Scale}

Cyber Bullying Scale was developed by Arıcak et. al (2012) for the purpose of assessing cyber bullying behaviors of adolescents. The scale consists 24 , four point Likert type items. The possible highest score that can be obtained from the scale is 96 and the possible lowest score that can obtained is 24 . The high scores indicate higher levels of cyber bullying behaviors. In the reliability and the validity study of the scale, the Cronbach alpha coefficient of the scale was found to be .95 (Arıcak et al., 2012). In this study the Cronbach alpha coefficient for the Cyber Bullying Scale was found to be .89 .

\subsubsection{Internet Addiction Scale}

Internet Addiction Scale is developed by Günüç and Kayri (2010) for the prupose of assessing internet addiction. The scale is comprised of 35, five point Likert items. The lowest possible score is 35 whereas the highest possible score is 175 . The high scores indicate the high level of internet addiction. When the scale is administered in a sample group, initially the mean and the standart deviation of the sample is calculated. The individual scores higher then the summation of mean and standart 
deviation indicate internet addiction (Internet Addiction> Mean + Standart Deviation). The Cronbach alpha coefficient of the scale was found to be .944 by Günüç and Kayri (2010). The Cronbcah alpha coefficient of Internet Addiction for this study was found to be .945

\subsection{Data Collection and Data Analysis}

Initially, the written consents of the authors of the instruments used in the study were provided. Prior to the onset of the data collection, the school administrations were given information about the study and their permissions were provided. In each classroom the students were informed about the study and verbal consent was taken from the adolescents who were willing to participate in the study. The ethical concerns were adjusted and the students were told that their anonymity was assured. In order to provide confidentiality and anonymity the teachers were informed about the study and they were asked to leave the classroom during the administrations.

After the data collection a preliminary analysis was performed in order to test the normality of the data collected (Runyon et al., 1999). Conformity of the data to the normality distribution was assessed by the Kolmogorov-Smirnov test. According to the results of the normality test, the data related to the scores of the scales used in the scale was found out to be nonparametric. Hence, Spearman Correlation test was used in the statistical analysis of the data collected (Field, 2009; Balcl, 2015). The data was analyzed using Statistical Package for Social Sciences 21(SPSS).

\section{FINDINGS AND DISCUSSIONS}

When the research findings are examined; The following results have been achieved;

Table 1: The Arithmetic Mean and The Standard Deviations of The Scores of Cyber Bullying Scale and Internet Addiction Scale for Adolescent

\begin{tabular}{lccccc}
\hline Scores & $\mathbf{N}$ & Minimum & Maksimum & $\bar{X}$ & ss \\
\hline Internet Addiction Scale & 239 & 35 & 175 & 81,93 & 27,16 \\
\hline Cyber Bullying Scale & 239 & 24 & 60 & 27,09 & 5,47 \\
\hline
\end{tabular}

The Table 1 shows the arithmetic mean and the standard deviations of the Internet Addiction and Cyberbullying Scales scores. It is seen that the scores of the Cyberbullying Scale vary between $24-60$ and the mean score is $27,09 \pm 5,47$. In regards with the Internet Adiction Scale, it is seen that the scores vary between 35-175. The mean score of Internet addiction scale is $81,93 \pm 27,16$. Of the 239 adolescents included in the study, 33 were found to be in the risk group in terms of internet addiction. The average score of the adolescents determined to be in the risk group is $129,33 \pm 16,91$ and the score interval is $110-175$.

Table 2: The Spearman Correlation Coefficients Between The Scores of Cyberbullying Scale and Internet Adiction Scale

\begin{tabular}{lccc}
\hline Scores & $\mathbf{N}$ & $\mathbf{r}$ & $\mathbf{p}$ \\
\hline $\begin{array}{l}\text { Internet Addiction Scale } \\
\text { Cyberbullying Scale }\end{array}$ & 239 & 374 & $0,000^{* *}$ \\
\hline
\end{tabular}

$* * p<0,01$

An examination of Table 2, related to the Spearman correlation coefficients between the scores of Cyberbullying Scale and the Internet addiction Scale, reveals that there is a significant positive correlation between cyberbullying and Internet addiction $(r=, 374, p<0,01)$

When Table 1 is examined, it is seen that Internet Addiction Scale scores of adolescents are between 35-175. Cyberbullying scale scores of adolescents are between 24-60. 33 of 239 adolescents included in the study were determined to be internet addicts.

When the literature performed on internet addiction in worldwide and Turkey;

Sanders, Field, Diego and Kaplan (2000) have concentrate on their researches relationship between intense internet use and social loneliness and depression. At the result of research, it was revealed that adolescents who used gradually more internet can't receive enough social support and their families were closed to communication.It was offered that duration of Internet use is low in adolescents whose relationship with their families and friends.

Kraut et.al (2002) investigated relationship between internet use reasons and social environment in their research. Internet use frequency is increasing in adolescents who have low communication within family and among friends. Being isolated of 
adolescent directs individual to internet use. Because individuals create social environment themselves in the internet. It is mentioned that the main way to overcome this is to strengthen communication within the family.

In the study by Johansson and Götestam (2004) on 3237 Norwegian young people by aiming of internet addiction, they specified that rate of non-internet users is $4,9 \%$, rate of non-internet users frequently is $35,8 \%$ and rate of frequent-internet users is $49.6 \%$. $1,98 \%$ of participants is internet addict and $8,68 \%$ of them is risky internet users. Weekly approximate internet use duration is 4.3 hours between findings of study.

In the study of internet tool use reasons of adolescent students examined by Mossbarger (2008), he expressed that they have used internet as fun. Adolescent students are able to solve the need for communication that can't meet and support get around thanks to this tool. But, this situation revealed addiction symptoms on adolescents.

In the study conducted between the ages of 11 and 16 including 18,709 adolescents by Kalmus, Blinka and Olafsson (2013) in order to investigate relationship between adolescents' excessive internet use and family environment, relationship between active familial environment on internet use of children (children were harmed online) and restrictive environment at low level was found. When family attitude is consistent with family internet use, this situation is predicted negatively. When family attitude is contradicted with their internet use, family attiude predicts internet addiction positively.

In the study conducted by Bayraktar (2001), he aimed to examine the effect of internet addiction on adolescents in the Turkish Republic of Northern Cyprus. His research has shown that internet use by male adolescents is greater than the use of female adolescents. At the same time, it seems that children of well-financed families use internet more. The researcher scrutinized communication over internet and concluded that adolescents described themselves in a very different way. It appeared that adolescents behaving like this felt serious concerns on trust to the other side.

In a thesis study in $\mathbf{2 0 0 6}$ was aimed to present wide perspective relation to internet use of high-school students and reveal reasons of variables that may occur in this issue. Increasing in internet use rapidly brought along some problems. At the result of study, it revealed that internet of redundant use led to addiction. A significant relationship was found between internet addiction and pleasure sensation in the research conducted on 296 adolescent students. In addition to this, it has been found out that it is related to internet addiction in the reasons such as family situation, geographical location and social environment (Aslanbay, 2006).

Esen (2007) examined that level peer pressure and perceived social support variables at which level predicted internet addiction. At the result of study for this purpose conducted on 479 high school-students, he found that peer pressure predicted internet addiction positively, perceived family and teacher support predicted negatively and these three variables explained $33 \%$ of internet addiction.

In the thesis study prepared by Turnalar-Kurtaran (2008) examined that contributions of lonelines, depression and self variables was on prediction of internet addiction.For this purpose, they included 650 students sample who studied at the general, occupational and Anatolian high schools in the centre of Mersin. They applied to determine students of internet addiction level "Internet Addiction Scale" developed by Young (1998b) and translated into Turkish by Bayraktar (2001) and tested as validity and reliable. As a result of study, it has been seen that self respect predicted internet addiction negavitely, loneliness predicted it positively but depression predicted statistically insignificant.

When the relevant literature was evaluated, it can be marked that lack of enough peers of them can contact socially among reasons pushing adolescents to internet addiction and their weak family relations.

When Table 2 was examined, it has been seen that significant relationship at highest degree $(r=, 378, p<0,01)$ between Internet Addiction Scale and Cyberbullying Scale scores statistically.

In order to determine situations cyberbullying and exposed to cyberbullying of high school students conducted by Sarak's study (2012), he applied "Virtual Bully/Victim Scale". At the result of study, he determined as students' age increase, virtual bully/victim being rate situations are higher. Besides, it has been determined whose family education level was literate and under this, having low academical success and adolescents and those who got psychiatric support in internet cafe showed more cyberbullying and exposed to cyberbullying tendencies. Also, it has been determined more internet use frequency and class level were higher, more they were cyber victims.

In the study conducted by Erdur-Baker and Kavgut (2007) in order to determine cyberbullying behaviours of high school students and examine their internet-mobile phones use, they collected data after application of questionnaire to total 228 student from three different high schools. At the end of study, it has been obtained that cyberbullying was also in our country, males showed cyberbullying and exposed to cyberbullying more than females. In addition, it has been concluded that internet use frequency affected being cyberbully/victim positively but no relation to being cyberbully and victim variables such as school type, family socio-economical level, age and class level.

Jung et.al (2014) compared relationship between cyberbullying behaviours and problematic internet use evaluation and psycopathological symptoms young people who were between cyber victims and didn't have cyberbullying. In the study 
conducted 4531 between $11-14$ ages in Korea, they concluded that $9,7 \%$ of young people showed cyberbullying behaviours, $3,3 \%$ of them was only victims, 3,4 of those was only bullies and $3 \%$ of them was both victims and bullies.

About scientifical data and their measurement including cyberbullying by Ybarra, Boyd, Korchmaros and Oppenheim (2012), in the study of 1200 people between 6-17 ages, it has been determined that $25 \%$ of participants showed cyberbullying at least one time a month including $10 \%$ of them was while online, $7 \%$ of those by phone calls and $8 \%$ of them by message.

In the study of 1431 people (726 females, 682 males) between 12-17 conducted by Calvete, Orue, Estévez, Villardón and Padilla, (2010) in Spain, it has been determined that $44,1 \%$ of adolescents showed cyberbullying at least one time and cyberbullying rates of male were higher than female.

In the study of adolescents between 12-17 ages conducted by Calvete, Orue, Estévez, Villardón and Padilla, (2010) in Spain, it has been found that $44.1 \%$ of adolescents showed at least one time, with regard to sexuality variable, males were higher than females on cyberbullying.

In the study of adolescents between 10-17 ages conducted by Ybarra and Mitchell (2007), they informed that 6\% of adolescents showed frequently cyberbullying behaviours, $6 \%$ of them showed it sometimes and $17 \%$ of them showed it in a limited way. As a result of study, as density of bullying behaviours increased, currency of behaviour and psychological problems was higher.

In the study by Özdemir and Akar (2011), it has been determined that $14 \%$ of high school students were exposed to cyberbullying and $10 \%$ of them showed cyberbullying. It has been understood that cyberbullying was showed in the social networking site that it was frequently there and mobile phones and it has been seen that demographical variables had no effect on cyberbullying. On the other hand, it was found that participants who exceeded 5 hours internet use duration showed more cyberbullying behaviours than other groups.

When studies relation to cyberbullying were evaluated, it was found that cyberbullying generally came to light in adolescents who used internet in a density way, existence and increasing psychological problems together with cyberbullying are remarkable.

\section{CONCLUSION}

Suggestions below may be presented within the frame of findings from obtained in the study;

Firstly, students are detracted from virtual environment and should be made socializing in their real life and are directed to different activities that can obtain more friends and environments and places that can be social such as sport, cinema, theathre

This study was performed on students from two different high schools. A greater part of sampling comprises of females. In this context, studies on different sampling groups and balanced sampling within the frame of sexuality variable can be suggested.

A similar study through wider age range, together with students who are at all levels from primary schools to higher education may be performed.

Data in this study was collected from students who study in different high school types in istanbul. Relationship between internet addiction and cyberbullying behaviours may be investigated in different cities and high school types.

This study was formed by quantitative data collecting method. To generalize it and present various perspectives, studies including qualitative data collecting methods may be performed.

Drama training which increases practical awareness on internet addiction and virtual cyberbullying can be given especially to students.

For generalizing internet addiction and cyberbullying behaviours, Turkey profile research may be carried out at various education levels based on different regions and variables.

\section{REFERENCES}

Arıcak, O.T. 2011, "Siber zorbalık: gençlerimizi bekleyen yeni tehlike”. Kariyer Penceresi, vol.2, no.6,pp.10-12.

Aslanbay, M. 2006. A compulsive concumption: internet use addiction tendency. The case of Turkish high school students. Yayınlanmış Yüksek Lisans tezi, Marmara Üniversitesi, Sosyal Bilimler Enstitüsü, İşletme Anabilim Dalı, Üretim Yönetimi ve Pazarlama Bilim Dalı: İstanbul.

Balcı, A. 2015 . Sosyal Bilimlerde Araştırma Yöntem Teknik ve İlkeler. (11. Baskı). Ankara: Pegem Akademi. 
Bayraktar, F. 2001. Internet Kullanımının Ergen Gelişimindeki Rolü. Ege Üniversitesi Sosyal Bilimler Enstitüsü Psikoloji Ana Bilim Dalı.Yayımlanmamış Yüksek Lisans Tezi: İzmir.

Calvete, E., Orue I., Estévez, A., Villardón, L., \& Padilla,P., 2010." Cyberbullying in adolescents: Modalities and aggressors' profile", Computers in Human Behavior Vol.26,pp. 1128-1135.

Cengizhan, C. 2005. Öğrencilerin Bilgisayar ve Internet Kullanımında Yeni Bir Boyut: Bağımlılık. Erişim Tarihi: 14 Nisan 2017. http://mimoza.marmara.edu.tr/ cahit/Yayin/bil-diri/PDR2005Bil/PDR2005_Bildiri.pdf

Erdur-Baker, Ö., Kavgut, F., 2007." Akran Zorbalığının Yeni Yüzü: Siber Zorbalık”. Eurasian Journal of Educational Research, 27, pp.31-42.

Esen, N. K. 2007. Akran Baskııı ve Algılanan Sosyal Destek Değişkenlerine Göre, Ergenlerde Internet Bağımlıı̆̆ının Yordanması. I. Uluslararası Bağımlılık Kongresi. ( 28- 31 Mayıs 2007).istanbul.

Field, A. 2009. Discovering Statistics Using SPSS. London: Sage Publications, pp.: 148.

Günüç, S., Kayri, M. 2010. "The profile of internet dependency in Turkey and development of Internet Addiction Scale: Study of validity \& reliability". Hacettepe University Journal of Education, Vol.39: pp.220-232.

Jung, Y. E., Leventhal, B., Kim, Y. S., Park, T. W., Lee, S. H., Lee, M., Park, S.H., Yang, J.C., Chung, Y.C., Chung, S.K. ve Park, J. I. 2014. Cyberbullying, problematic internet use, and psychopathologic symptoms among Korean youth. Yonsei medical journal,55(3), pp.826-830.

Johanssons, A. ve Götestam, K. G. 2004. Internet addiction: Characteristics of a questionnaire and prevalence in norwegian youth (12-18 years). Scandinavian Journal of Psychology. 45(3),pp. 223-229

Kalmus, V., Blinka, V., Olafsson, K. 2013. Does it matter what mama says: Evaluating the role of parental mediation in European adolescents" excessive internet use. Children and Society, 29(2), pp.122-133.

Kraut, R., Patterson, M., Lundmark, V., Kiesler, S., Mukhopadhyay, T. ve Scherlis,W. 2002. Internet paradox: a social technology that reduces social involvement and psychological well-being?. Journal of Social Issues, 58 (1), pp.49-74.

Mossbarger, B. 2008. Is "Internet addiction" addressed in the classroom? A survey of psychology textbooks. Computers in Human Behavior, 24(2),pp. 468-474

Özen, Y., Gülaçtı, F. ve Çıkılı, Y. 2004. Eğitim bilimleri ve internet. Fırat Üniversitesi Doğu Anadolu Bölgesi Araştırmaları,pp. 52-57.

Öztürk, Ö., Odabaşıŏlı, G., Eraslan, D., Genç, Y., Kalyoncu, Ö.A. 2007. İternet Bağımlıı̆ığ: Kliniği ve Tedavisi. Bağımlılık Dergisi, 8 (1), pp.3641.

Runyon, R., Coleman, K., Pittenger, D. (1999) Fundamentals of Behavioral Statistics. New York: McGraw Hill

Sarak, Ö. 2012. Lise öğrencilerinde sanal zorbalık. Yayınlanmamış Yüksek Lisans Tezi, Sağlık Bilimleri Enstitüsü, Haliç Üniversitesi, İstanbul.

Şendağ, S. ve Odabaşı, H.F. 2007. İnternet bağımlılığı: Çocukların psikososyal gelişimi üzerindeki etkileri. International Educational Technology Conference, (3-5 May 2007), Near East University-North Cyprus.

Özdemir, M. \& Akar, Ö. 2011. Lise Öğrencilerinin Siber-Zorbalığa Ilişkin Görüşlerinin Bazı Değişkenler Bakımından İncelenmesi. Kuram ve Uygulamada Eğitim Yönetimi, 17( 4), pp.605-626.

Sanders, C.E., Field, T.M., Diego, M. ve Kaplan, M. 2000. "The Relationship of Internet to Depression and Social Isolation Among Adolescents", Adolescence, 35 (138),pp.237-242.

Tsai, C. C., Lin, S. S. J., 2003. Internet addiction of adolescents in Taiwan: An interview study. CyberPsychology \& Behavior, 6(6), pp.649-652.

Turnalar-Kurtaran, G., 2008. Internet Bağımlılı̆ııı Yordayan Değişkenlerin Incelenmesi. Mersin Üniversitesi Sosyal Bilimler Enstitüsü, Yüksek Lisans Tezi, Mersin.

TÜik 2008 Yılı Hane Halkı Bilişim Teknolojileri Kullanım Araştırması. (2008). Erişim Tarihi: 14 Nisan 2017, http://www.linkopedi.com/cesitli/tuik-2008-yili-hane-halki-bilisim-teknolojileri-kullanim-aras-tirmasi/.

Üneri, ş. Ü. ve Tanıdır, C. 2011. Bir grup lise öğrencisinde internet bağımlılığı değerlendirmesi: Kentsel çalışma. Düşünen Adam Psikiyatri ve Nörolojik Bilimler Dergisi, 24, pp.265-272.

Ybarra, M.L., \& Mitchell, K.J. 2004a. Online aggressor/targets, aggressors, and targets: A comparison of associated youth characteristics. Journal of Child Psychology and Psychiatry, 45,pp. 1308-1316.

Ybarra, M. L., Boyd, D., Korchmaros, J. D. ve Oppenheim, J. K. 2012. Defining and measuring cyberbullying within the larger context of bullying victimization. Journal of Adolescent Health, 51(1),pp. 53-58.

Young, K. S. 1996. Internet addiction: The emergence af a new clinical disorder. CyberPsychology and Behavior, 1(3), pp.237-244. 